\title{
ヨウ素酸カリウムを用いるメチオニンと “メチオニン スルホキシド”の電流滴定 ${ }^{122}$
}

\author{
（1985 年 10 月 3 日 受 理）
}

池田早苗*・佐竹弘

\begin{abstract}
メチオニン扣よび “メチオニンスルホキシド”をヨウ素酸イオンで簡単に定量する電流滴定法を開発 した。回転白金電極（+0.6 V vs. SCE）を指示電極，SCE を対極とし，ヨウ素酸カリウム標準液で

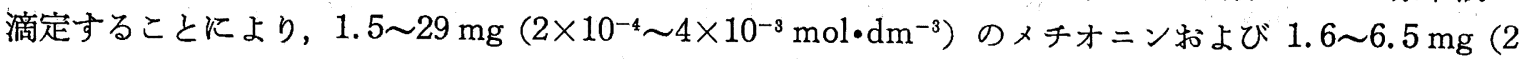
$\left.\sim 8 \times 10^{-4} \mathrm{~mol} \cdot \mathrm{dm}^{-3}\right)$ のメチオニンスルホキシドが $0.3 \%$ 以内の相対誤差と変動俰数で定量できた。 約 $45^{\circ} \mathrm{C}$ の $3 \mathrm{~mol} \cdot \mathrm{dm}^{-3}$ 塩酸に塩化ナトリウム $(12 \mathrm{~g})$ を飽和した溶液 $\left(50 \mathrm{~cm}^{3}\right)$ 中で, ヨウ素酸カリ ウム標準液を 5 秒ごとに $0.05 \mathrm{~cm}^{8}$ ずつ滴下して滴定するのが適当であった。共存物質として無機塩類 やアミノ酸類などの影響について検討した。

本法は滴定試薬に JIS 標準試薬を用いるため標準液の調製が容易で標定の必要がなく、メチオニン とメチオニンスルホキシドを迅速かつ精度よく定量できるといら特徵がある。
\end{abstract}

\section{1 緒言}

メチオニンは必須含硫アミノ酸として生体内に存在し，種々薬 物のメチル転位, システインの合成などに重要な生理活性物質で ある。また，医薬品，食品用の栄養剤や飼料の添加剤としての需 要が大きい重要な化学物質 ${ }^{3}$ である。メチオニンの分析方法には, 臭素滴定法 ${ }^{4)}$, 臭素酸塩滴定法4)，二クロム塩酸滴定法5)虾よびョ

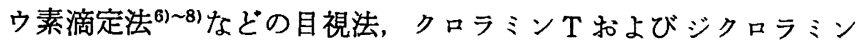
Tなどを滴定剤とする電位差滴定法 ${ }^{910}$ など数多く報告されてい る。“メチオニンスルホキシド”（メチオニンS-オキシド）はメチ オニンの酸化生成物であり，その分析法には“メチオニンスルホ ン”（メチオニン $S, S$-ジオキシド)への酸化反応やメチオニンへ の還元反応を利用した方法 ${ }^{11}$ がある。メチオニンスルホキシドの

德島大学工業短期大学部, 770 德島市南常三島町

1）この報文を“回転白金電極を指示電極とする電流滴定法に 関する分析化学的研究 (第 51 報)”とする.

2）前報(第 50 報), 佐竹 弘, 池田早苗, 日化, 1985, 2255 .

3）奥村信二, 化学と工業, 27, 351(1974).

4) A. P. Deliyannis, Chim. Chroni., 22, 22(1957); Chem. Abstr., 56, $13188 \mathrm{~d}(1962)$.

5) M. F. EL-Tarros, M. M. Amer, N. B. Tadros, M. R. Zawahry, Bull. Fac. Pharm., Cairo Univ., 14, 11 (1975) ; Chem. Abstr., 87148310 t(1977).

6）日本公定書協会編，“日本薬局方”，第 9 改正版 (1976) C1324.

7) Z. Kurzawa, Chem. Anal., 6, 399(1961); Chem. Abstr., 56, 41086(1962).

8) W. A.Schroeder, L. Kay, R.S. Mills, Anal. Chem., 22, $760(1950)$.

9) G.E. Trout, Anal. Biochem., 93, 419(1979).

10) N. M. M. Gowda, D. S. Mahadevappa, Talanta, 24, 470(1977).
定量方法は一般に操作が煩雑で, 低濃度まで直接定量できる方法 はなく十分確立した方法は報告されていない。また，JIS 標準試 薬であるョウ素カリウムで直接電流滴定した例は見あたらない。

著者ら ${ }^{12}$ はさきに回転白金電極 $(2000 \mathrm{rpm})$ を指示電極，飽和 カロメル電極 (SCE) を対極として，システイン拈よびシスチン をヨウ素酸カリウム標準液で電流滴定する方法を報告した。今回 は塩酸一塩化ナトリウム基礎茌中でメチオニンとメチオニンスル ホキシドを電流滴定する方法を検討した。すなわち，滴定途中に 批りる被滴定液の電流-電位曲線と滴定曲線の形状との関係を調 べそその反応を吟味し，最適な定量条件を決定した。

\section{2 試薬, 装置および実験方法}

\section{1 試 薬}

DL-メチオニン：和光純薬試薬特級 $\mathrm{DL}$ メメチオニンの一定量を 除酸素水 $20 \mathrm{~cm}^{3}$ と $10 \mathrm{~mol} \cdot \mathrm{dm}^{-3}$ 壏酸 $10 \mathrm{~cm}^{3}$ に溶解したのち, 水で全量を $500 \mathrm{~cm}^{3}$ として $10^{-2} \mathrm{~mol} \cdot \mathrm{dm}^{-3}$ 溶液を調製して日本 薬局方6)で標定した。

DLーメチオニンスルホキシド：片山化学試薬特級 DLーメチオニ ンスルホキシドの一定量を DL-メチオニンと同様に溶解して, $4 \times 10^{-3} \mathrm{~mol} \cdot \mathrm{dm}^{-3}$ 溶液を調製した。2.3.1 の方法で標定して用い た。この結果から試㭗の純度を求めたところ $98.60 \%$ であった。 な拈，上記の試料溶液は窒素ガス中に保存し，必要に応じて水で 適当に希釈して用いた。

その他の試薬は特級品または既報 ${ }^{12)}$ と同様なものを用い，水は すべてイオン交換水を 1 回蒸留して窒素で除酸素したるのを使用

11) M. R.F. Ashworth, "The Determination of Sulfurcontaining Groups", Vol.1, Academic Press, London (1972) p. 31.

12）佐竹 弘, 池田早苗, 田中雅美, 日化，1981，1726. 

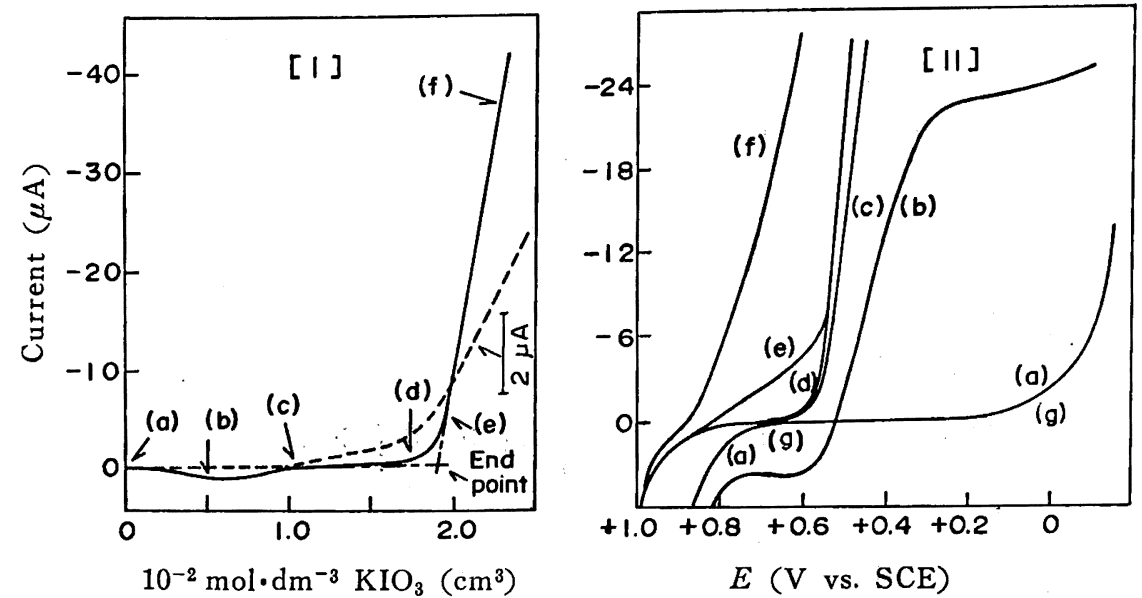

Fig. 1 A titration curve and the corresponding current-potential curves

Sample solution $\left(50 \mathrm{~cm}^{3}\right)$ contains $10 \mathrm{~cm}^{3}$ of $2 \times 10^{-3} \mathrm{~mol} \cdot \mathrm{dm}^{-3} \mathrm{DL}-$ methionine, $15 \mathrm{~cm}^{3}$ of $10 \mathrm{~mol} \cdot \mathrm{dm}^{-3} \mathrm{HCl}$ and $12 \mathrm{~g}$ of $\mathrm{NaCl}$

[I] Applied potential : $+0.6 \mathrm{~V}$ vs. SCE, Titration rate $: 0.05 \mathrm{~cm}^{3} / 5 \mathrm{~s}$, Temp. : $45^{\circ} \mathrm{C}$

[II] Voltage scan rate: $10 \mathrm{mV} / \mathrm{s}$, Temp. : $45^{\circ} \mathrm{C}$

(g) : $50 \mathrm{~cm}^{3}$ of $3 \mathrm{~mol} \cdot \mathrm{dm}^{-3} \mathrm{HCl}$ and $\mathrm{NaCl}(12 \mathrm{~g})$

- - : Sample solution $\left(50 \mathrm{~cm}^{3}\right)$ contains $10 \mathrm{~cm}^{3}$ of $2 \times 10^{-4} \mathrm{~mol} \cdot \mathrm{dm}^{-3} \mathrm{DL}-$ methionine, $15 \mathrm{~cm}^{3}$ of $10 \mathrm{~mol} \cdot \mathrm{dm}^{-3} \mathrm{HCl}$ and $12 \mathrm{~g}$ of $\mathrm{NaCl}$, Titrant : $10^{-3} \mathrm{~mol} \cdot \mathrm{dm}^{-3}$ $\mathrm{KIO}_{3}$, Temp. : $45^{\circ} \mathrm{C}$

した。

\section{2 装置}

既報13144) と同様な自動滴定装置およ゙び゚ーラログラフを用い た。

\section{3 実験方法}

2.3.1 メチオニンの定量：滴定セル $\left(100 \mathrm{~cm}^{3}\right.$ ビーカー) に $10 \mathrm{~mol} \cdot \mathrm{dm}^{-3}$ 塩酸 $15 \mathrm{~cm}^{3}$, 結晶塩化ナトリウム $12 \mathrm{~g}$ と水 $25 \mathrm{~cm}^{3}$ を添加する。約 $45^{\circ} \mathrm{C}$ にしたのち, $10^{-4} \sim 10^{-2} \mathrm{~mol} \cdot \mathrm{dm}^{-3}$ の DL-メ チオニン溶液 $10 \mathrm{~cm}^{3}$ を正確にはかりとる。回転白金電極 $(+0.6$

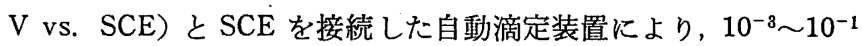
$\mathrm{mol} \cdot \mathrm{dm}^{-3}$ ヨウ素酸カリウム標準液を $5 \sim 20$ 秒ごとに $0.05 \mathrm{~cm}^{3}$ ずつ滴下して滴定する (約 $\left.45^{\circ} \mathrm{C}\right)$ 。分析值はつぎの当量関係から 求める。

$$
\begin{array}{r}
10^{-2} \mathrm{~mol} \cdot \mathrm{dm}^{-3} \mathrm{KIO}_{3} 1 \mathrm{~cm}^{3}=1.492 \mathrm{mg} \\
\operatorname{HOOCCH}\left(\mathrm{NH}_{2}\right) \mathrm{CH}_{2} \mathrm{CH}_{2} \mathrm{SCH}_{3}
\end{array}
$$

2.3.2 メチオニンスルホキシドの定量：DLーメチオニンスルホ キシド溶液 $\left(2 \times 10^{-4} \sim 4 \times 10^{-3} \mathrm{~mol} \cdot \mathrm{dm}^{-3}\right) 10 \mathrm{~cm}^{3}$ を用いて，2.3. 1 と同様に滴定した。

$$
\begin{aligned}
& 10^{-2} \mathrm{~mol} \cdot \mathrm{dm}^{-3} \mathrm{KIO}_{3} 1 \mathrm{~cm}^{3}=3.304 \mathrm{mg} \\
& \operatorname{HOOCCH}\left(\mathrm{NH}_{2}\right) \mathrm{CH}_{2} \mathrm{CH}_{2} \mathrm{~S}(=\mathrm{O}) \mathrm{CH}_{3}
\end{aligned}
$$

\section{3 結果および考察}

\section{1 メチオニンの滴定曲線}

著者ら ${ }^{12}$ はさきに回転白金電極と SCE を用いて $4 \mathrm{~mol} \cdot \mathrm{dm}^{-3}$ 塩酸基礎液中でョウ素酸イオン, 塩化ヨウ素などョウ素化合物の 電流一電位曲線を測定し，その結果をもとにシステインなどのヨ

13）佐竹 弘, 池田早苗, 分析化学, 28, 468(1979).

14）佐竹 弘, 池田早苗, 日化, 1984, 1393.
ウ素酸イオンとの反応を考察した。今回はメチオニンとヨウ素酸 イオンとの反応を検討する目的で, DL-メチオニン $\left(2 \times 10^{-3} \mathrm{~mol}\right.$. $\left.\mathrm{dm}^{-3}, 10 \mathrm{~cm}^{3}\right)$ を用いて，2.3.1 と同様に滴定した場合の滴定曲 線と滴定途中における被滴定液の電流-電位曲線を記録したとこ ろ，図1のよらな結果が得られた。

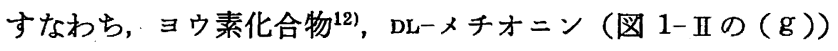
および図 1-II の電流-電位曲線から考察すると, 滴定曲線（図 1 の [ I ] ) (a) の部分の試料の酸化電流は DL-メチオニンによる ものである。(b) の部分の試料では $+0.5 \mathrm{~V}$ 付近を境に酸化電 流と還元電流を示す曲線となることからョウ素と塩化ヨウ素が,

(c) と (d) の部分では還元電流のみ与えることから塩化ヨウ素 が共存するるのと考光られる。（e）と（f）の部分では大きな還 元電流が測定されていることから, 過剩のヨウ素酸イオンと生じ た塩化ヨウ素によるるのと推察される。

したがって, SCE に対して $+0.6 \mathrm{~V}$ の電位に設定して滴定し た場合の滴定曲線（図1の［I］）について考察するとつぎのよう になる。すなわち、ヨウ素酸カリウムを試料溶液に滴下すると， これが DL-メチオニンと反応して，一部ヨウ素を生成するために ヨウ素の酸化電流が測定される。つづいて滴下するヨウ素酸かリ ウムで DL-メチオニンおよび生成したヨウ素が塩化ヨウ素に酸化 されて、ヨウ素の酸化電流が減少する。終点のほぼ半分付近から 零電流となり, 終点後はヨウ素酸イオンの還元電流が得られる滴 定曲線となる。

以上のことから, $3 \mathrm{~mol} \cdot \mathrm{dm}^{-3}$ 塩酸に塩化ナトリウムを飽和し た基礎液中での DL-メチオニンとヨウ素酸イオンとの反応は，滴 定曲線の ( a ) 一 (b) の範囲では式 (1) 亿示すように, DL-メチ オニン $2 \mathrm{~mol}$ とヨウ素酸イオン $1 \mathrm{~mol}$ とが反応して DL-メチオニ ンスルホキシドと塩化ョウ素を生成する。さらに，生成した塩化 ヨウ素と DL-メチオニンが式(2)のよらに反応し、一部ヨウ素を 


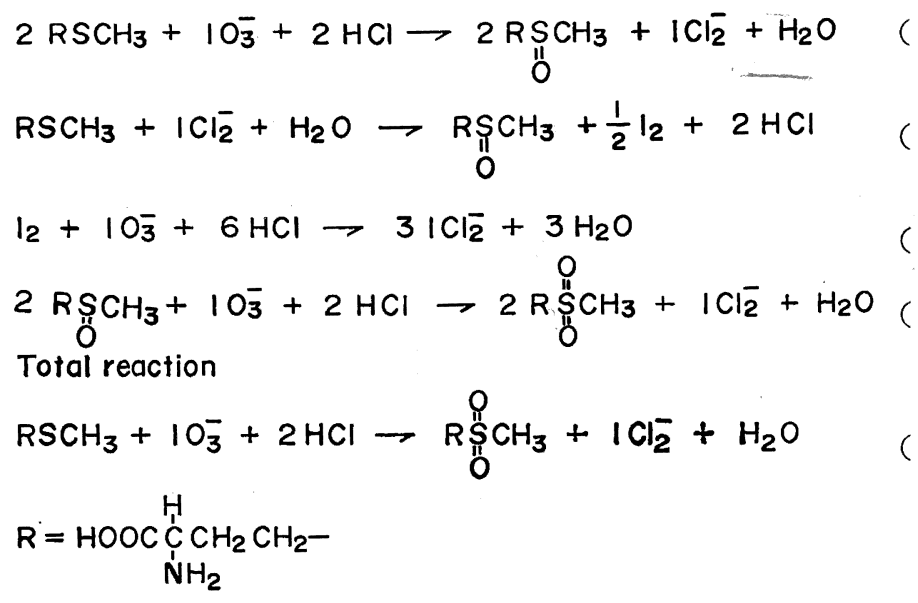

生成する。（b)—(c) の部分では式 (1) と式 (3) に示すョウ 素の塩化ヨウ素への酸化がともに進む。（c）から終点までは式 (4) に示すよらに，DL-メチオニンスルホキシド $2 \mathrm{~mol}$ とヨウ素 酸イオン $1 \mathrm{~mol}$ とが反応し，DL-メチオニンスルホンへ酸化され るものと考えられる。

以上の結果, 滴定曲線 [I ] の変曲点 $(\mathrm{c})$ から求めた分析值か ら考えると式(1)に示すように, DL-メチオニン $2 \mathrm{~mol}$ とヨウ素 酸イオン $1 \mathrm{~mol}$ が反応していると考えた場合とほぼ一致した。ま た零電流とヨウ素酸イオンの還元電流の交点から求めた分析値は 式(5)に示すよらに, DL-メチオニンとヨウ素酸イオンが $1: 1$ で 化学量論的に反応すると考えた場合とよく一致することがわか つた。

なお，低濃度の DLーメチオニン $\left(2 \times 10^{-4} \mathrm{~mol} \cdot \mathrm{dm}^{-3}, 10 \mathrm{~cm}^{3}\right)$ を 用いて同様に検討したところ, 因 1 の［I］の破線のよらな滴定 曲線を与えた。高濃度の場合にくらべて式 (2)によるョウ素の生 成は認められず，終点の半分付近からわずかに還元電流が上昇し た。以上のことから，低濃度では式 (1)の反応は速いが，式 (2) の反応は極端に遅くなり,さらに式(4)の反応も遅くなるものと 考えられる。

\section{2 メチオンスルホキシドの滴定曲線}

メチオニンスルホキシドを 2.3 .2 と同様に滴定した場合の滴 定途中に扣ける被滴定液の電流-電位曲線とその滴定曲線を調べ たところ，図2のような結果が得られた。

すなわち, 滴定曲線の(a)の部分の試料では酸化電流も還元電 流も示さないが，（b)と（c）の部分では還元電流を与え，これは 塩化ョウ素によるものと考㖷られる。(d)と（e）の部分では大き な還元電流を示すことから，ここでは過㮃のヨウ素酸イオンと生 じた塩化ョウ素が存在するものと考えられる。また, SCEに対し $\tau+0.6 \mathrm{~V}$ の電位に設定して滴定した場合の滴定曲線は図 2 の [I］のように逆 L字形となり，ヨウ素酸イオンの還元電流によ って終点が示される。

以上のことから, $3 \mathrm{~mol} \cdot \mathrm{dm}^{-3}$ 塩酸に塩化ナトリウムを飽和し た基礎液中のメチオニンスルホキシドとヨウ素酸イオンとの反応 により，塩化ヨウ素が生成していることは明らかである。また残 余電流とヨウ素酸イオンの還元電流の交点より求めた分析值から 考えて, 式(4)に示すように DL-メチオニンスルホキシド $2 \mathrm{~mol}$ とヨウ素酸イオン $1 \mathrm{~mol}$ とが化学量論的に反応して DLーメチオニ ンスルホンを生成しているものと考えられる。
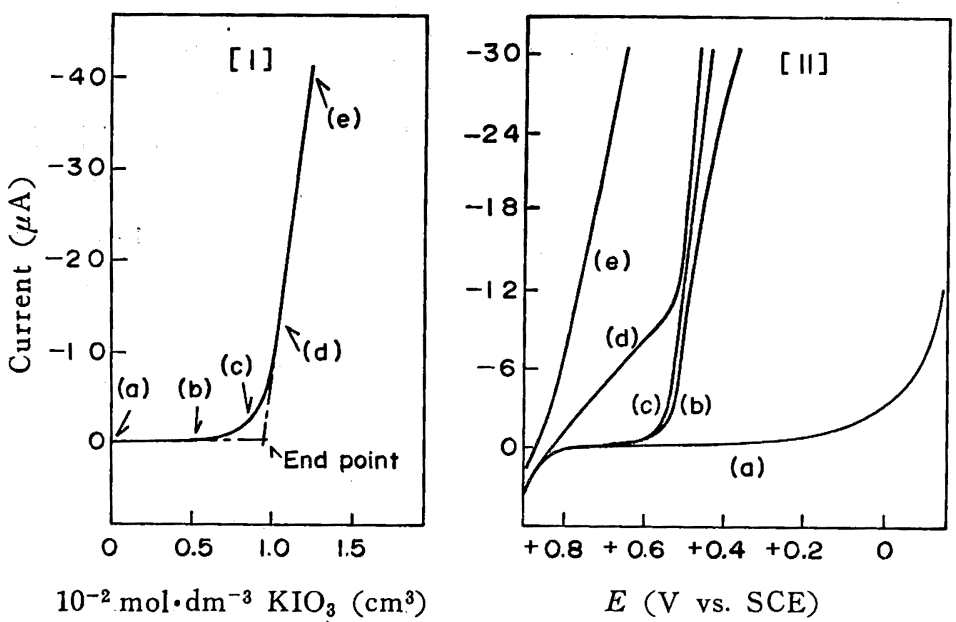

Fig. 2 A titration curve and the corresponding current-potential curves

Sample solution $\left(50 \mathrm{~cm}^{3}\right)$ contains $10 \mathrm{~cm}^{3}$ of $2 \times 10^{-3} \mathrm{~mol} \cdot \mathrm{dm}^{-3} \mathrm{DL}-\mathrm{methio-}$ nine sulfoxide, $15 \mathrm{~cm}^{3}$ of $10 \mathrm{~mol} \cdot \mathrm{dm}^{-3} \mathrm{HCl}$ and $12 \mathrm{~g}$ of $\mathrm{NaCl}$

[I] Applied voltage vs. $\mathrm{SCE}:+0.6 \mathrm{~V}$, Titration rate $: 0.05 \mathrm{~cm}^{3} / 5 \mathrm{~s}$, Titration temp. : $45^{\circ} \mathrm{C}$

[II] Voltage scan rate : $10 \mathrm{mV} / \mathrm{s}$, Temp. : $45^{\circ} \mathrm{C}$ 


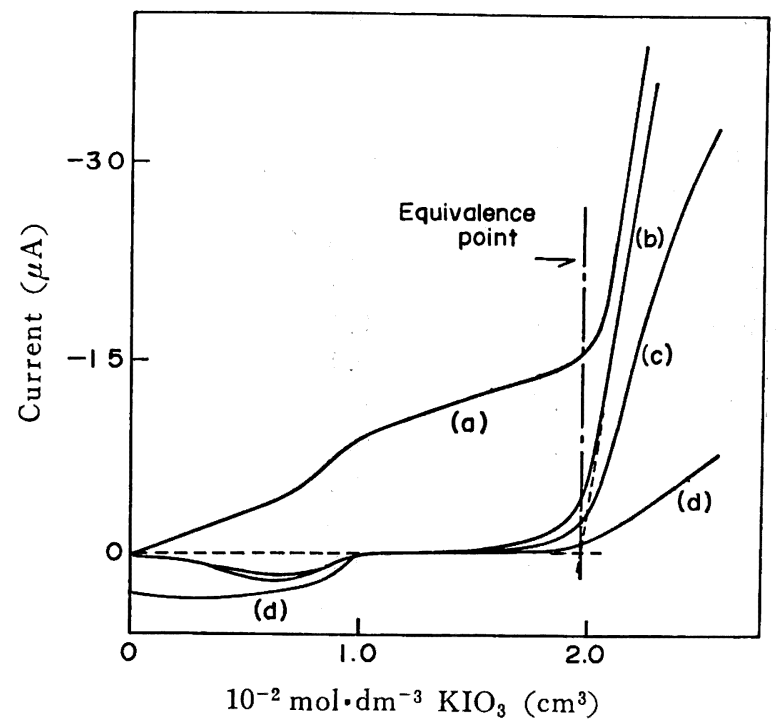

Fig. 3 Effect of applied potential on the titration curves of DL-methionine

Applied potential vs. SCE : (a) +0.5 V, (b ) +0.6 V, (c) $+0.7 \mathrm{~V}$, (d) $+0.8 \mathrm{~V}$

Sample solution $\left(50 \mathrm{~cm}^{3}\right)$ contains $10 \mathrm{~cm}^{3}$ of $2 \times 10^{-3} \mathrm{~mol}$. $\mathrm{dm}^{-3}$ DL-methionine, $15 \mathrm{~cm}^{3}$ of $10 \mathrm{~mol} \cdot \mathrm{dm}^{-3} \mathrm{HCl}$ and added $12 \mathrm{~g}$ of $\mathrm{NaCl}$

Titration rate $: 0.05 \mathrm{~cm}^{3} / 5 \mathrm{~s}$, Titration temp. : $45^{\circ} \mathrm{C}$

\section{3 設定電位の検討}

図1の [II] の電流-電位曲線の結果から考えると, DLーメチオ ニンを電流滴定する場合, ヨウ素酸イオンの還元電流 +0.7 $+0.55 \mathrm{~V}$ の範囲で測定するのが適当であるが， ヨウ素およびメ チオニンの酸化電流もともに測定されるので, メチオニンをヨウ 素酸カリウムで滴定する場合の設定電位と滴定曲線の形状との関 係を検討した。+0.5〜+0.8 V の範囲で種々電位に設定して電 流滴定したところ, 図 3 のよらな滴定曲線が得られた。

設定電位が高くなると終点後の指示電流の立ち上がりが小さく なるが， +0.55〜 +0.8V の範囲で計算值と一致する終点を示し た。とくに $+0.6 \mathrm{~V}$ の場合には精度のよい終点を与えるのでこ の電位に設定して電流滴定することにした。なお＋0.5Vでは (a)のように滴定により生成する塩化ヨウ素の還元電流が測定さ れ，残余電流の大きい滴定曲線を与えた。

また，DLーメチオニンスルホキシド $\left(2 \times 10^{-3} \mathrm{~mol} \cdot \mathrm{dm}^{-3}, 10 \mathrm{~cm}^{3}\right)$ について, 適当な設定電位を求めたところ, SCE に対して +0.55 〜 +0.75V の範团で一定した終点が得られ，とくに+0.6Vの 場合に安定した滴定曲線を与えた。

\section{4 塩酸濃度の影響}

DL-メチオニンと DL-メチオニンスルホキシドについて，敵定 時の塩酸濃度の影響を検討した。

図 4 に示すように, 両者ともに $2 \sim 6 \mathrm{~mol} \cdot \mathrm{dm}^{-3}$ で正確に定量 することができた。しかし，塩酸濃度が高くなるにつれて，これ らとヨウ素酸イオンとの反応が遅くなる傾向が見られた。なお塩 酸濃度が $3 \mathrm{~mol} \cdot \mathrm{dm}^{-3}$ 以下では塩化ナトリウム $12 \mathrm{~g}$ を添加して 滴定した。

以上のことから， DL-メチオニンと DL-メチオニンスルホキシ ドを電流滴定する場合には, $3 \mathrm{~mol} \cdot \mathrm{dm}^{-3}$ 塩酸溶液 $50 \mathrm{~cm}^{3}$ に塩化

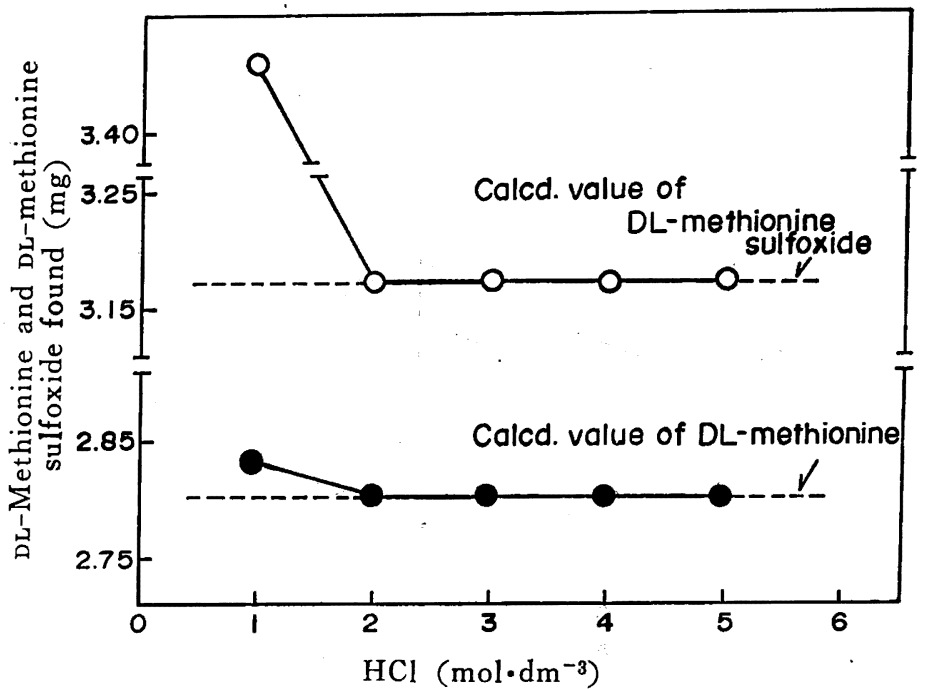

Fig. 4 Effect of hydrochloric acid concentration on the. determination of DL-methionine and DL-methionine sulfoxide

-O- : Sample solution $\left(50 \mathrm{~cm}^{3}\right)$ contains $10 \mathrm{~cm}^{3}$ of 2 $\times 10^{-3} \mathrm{~mol} \cdot \mathrm{dm}^{-3}$ DL-methionine and varying concentration of $\mathrm{HCl}\left(\leqq 3 \mathrm{~mol} \cdot \mathrm{dm}^{-3} \mathrm{HCl}\right.$ : Added $12 \mathrm{~g}$ of $\mathrm{NaCl}$ )

Titration rate $: 0.05 \mathrm{~cm}^{3} / 5 \mathrm{~s}$, Titration temp. : $45^{\circ} \mathrm{C}$

- - : Sample solution $\left(50 \mathrm{~cm}^{3}\right)$ contains $10 \mathrm{~cm}^{3}$ of 2 $\times 10^{-3} \mathrm{~mol} \cdot \mathrm{dm}^{-3}$ DL-methionine sulfoxide and varying concentration of $\mathrm{HCl}\left(\leqq 3 \mathrm{~mol} \cdot \mathrm{dm}^{-3}\right.$ $\mathrm{HCl}$ : Added $12 \mathrm{~g}$ of $\mathrm{NaCl}$ )

Titration rate $: 0.05 \mathrm{~cm}^{3} / 5 \mathrm{~s}$, Titration temp. : $45^{\circ} \mathrm{C}$

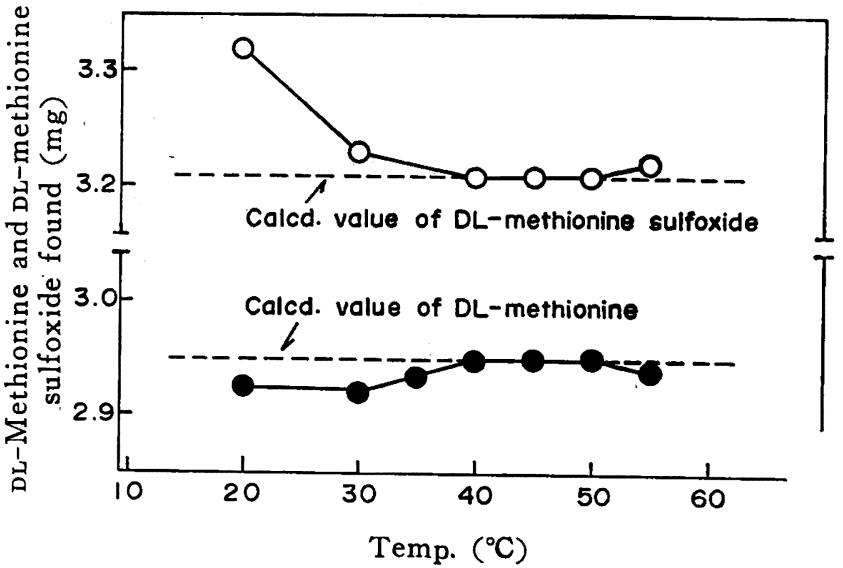

Fig. 5 Effect of temperature on the determination of DL-methionine and DL-methionine sulfoxide

- $\bigcirc-$ : Sample solution $\left(50 \mathrm{~cm}^{3}\right)$ contains $10 \mathrm{~cm}^{3}$ of 2 $\times 10^{-8} \mathrm{~mol} \cdot \mathrm{dm}^{-3}$ DL-methionine, $15 \mathrm{~cm}^{3}$ of 10 $\mathrm{mol} \cdot \mathrm{dm}^{-3} \mathrm{HCl}$ and added $12 \mathrm{~g}$ of $\mathrm{NaCl}$.

Titration rate $: 0.05 \mathrm{~cm}^{3} / 5 \mathrm{~s}$

- : Sample solution $\left(50 \mathrm{~cm}^{3}\right)$ contains $10 \mathrm{~cm}^{3}$ of 2 $\times 10^{-3} \mathrm{~mol} \cdot \mathrm{dm}^{-3}$ DL-methionine sulfoxide, 15 $\mathrm{cm}^{3}$ of $10 \mathrm{~mol} \cdot \mathrm{dm}^{-3} \mathrm{HCl}$ and added $12 \mathrm{~g}$ of $\mathrm{NaCl}$. Titration rate $: 0,05 \mathrm{~cm}^{3} / 5 \mathrm{~s}$ 
Table 1 Effect of titration rate on the determination of DL-methionine and DL-methionine sulfoxide

\begin{tabular}{|c|c|c|c|c|c|}
\hline & \multicolumn{2}{|c|}{$\begin{array}{l}\text { Concentration } \\
\left(\mathrm{mol} \cdot \mathrm{dm}^{-3}\right)\end{array}$} & \multirow{2}{*}{ Titration rate } & \multirow{2}{*}{$\begin{array}{l}\text { Relative } \\
\text { error }(\%)^{b)}\end{array}$} & \multirow{2}{*}{$\begin{array}{l}\text { Coefficient of } \\
\text { variation }(\%)\end{array}$} \\
\hline & Sample ${ }^{a)}$ & $\mathrm{KIO}_{3}$ & & & \\
\hline \multirow{5}{*}{ DL-Methionine } & $4 \times 10^{-3}$ & $10^{-1}$ & $0.025 \mathrm{~cm}^{3} / 2 \mathrm{~s}$ & -0.1 & 0.0 \\
\hline & $4 \times 10^{-4}$ & $10^{-2}$ & $0.05 \mathrm{~cm}^{3} / 5 \mathrm{~s}$ & -0.1 & 0.1 \\
\hline & $4 \times 10^{-4}$ & $10^{-2}$ & $0.05 \mathrm{~cm}^{3} / 10 \mathrm{~s}$ & -0.2 & 0.2 \\
\hline & $4 \times 10^{-4}$ & $10^{-2}$ & $0.05 \mathrm{~cm}^{3} / 20 \mathrm{~s}$ & -0.3 & 0.1 \\
\hline & $8 \times 10^{-5}$ & $10^{-3}$ & $0.05 \mathrm{~cm}^{3} / 20 \mathrm{~s}$ & +1.0 & 0.1 \\
\hline \multirow{4}{*}{$\begin{array}{l}\text { DL-Methionine } \\
\text { Sulfoxide }\end{array}$} & $4 \times 10^{-4}$ & $10^{-2}$ & $0.05 \mathrm{~cm}^{3} / 2 \mathrm{~s}$ & -1.3 & 0.3 \\
\hline & $4 \times 10^{-4}$ & $10^{-2}$ & $0.05 \mathrm{~cm}^{3} / 5 \mathrm{~s}$ & \pm 0.0 & 0.1 \\
\hline & $4 \times 10^{-4}$ & $10^{-2}$ & $0.05 \mathrm{~cm}^{3} / 10 \mathrm{~s}$ & -0.4 & $0.0_{4}$ \\
\hline & $8 \times 10^{-5}$ & $10^{-3}$ & $0.05 \mathrm{~cm}^{3} / 20 \mathrm{~s}$ & +1.7 & 0.2 \\
\hline
\end{tabular}

a) Sample solution: $50 \mathrm{~cm}^{3}$, Titration temp. $: 45^{\circ} \mathrm{C}$.

b) Average of four titrations.

ナトリウムを餙和させた基礎液を用いて滴定することにした。

\section{5 滴定温度の影響}

DL-メチオニンと DLーメチオニンスルホキシドの定量に扰よぼ す滴定温度の影響を検討したところ, 図 5 のような結果が得られ た。

すなわち, 両者ともに $40 \sim 50^{\circ} \mathrm{C}$ の範囲で精度のよい定量が可

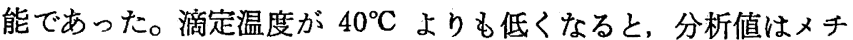
オニンの場合には小さくなり,メチオニンスルホキシドの場合に は大きくなる傾向を示した。これは両者ともに（メチオニンの場 合には終点の半分付近から）ヨウ素酸イオンとの反応が嬚くなり メチオニンスルホンへの酸化が定量的に進まず，メチオニンの場 合には負の誤差を、メチオニンスルホキシドの場合には残余電流 が高くなり終点の作図上分析值が大きくなったものと考えられ る。このことから, 約 $45^{\circ} \mathrm{C}$ で滴定することにした。

\section{5 滴下速度の影響}

ヨウ素酸イオンによるメチオニンスルホンヘの酸化が両者とも に遅いことから, 種々䟴度の試料を用い, 約 $45^{\circ} \mathrm{C}$ の滴定温度で 滴下速度の影響を検討した。

表 1 に示すように, 両者ともに滴定時の試料濃度が $4 \times 10^{-4}$ $\mathrm{mol} \cdot \mathrm{dm}^{-3}$ 以上では 5 20 秒ごとに $0.05 \mathrm{~cm}^{3}$ ずつ滴下して滴定 するのが適当であった。 $10^{-5} \mathrm{~mol} \cdot \mathrm{dm}^{-3}$ 程度では 20〜40 秒ごと の間隔で滴定することにより精度のよい定量が可能であった。

\section{6 共存物質の影響}

メチオニンはヨウ素酸イオンと反応して,メチオニンスルホキ シドをへて.メチオニンスルホンになることから，試料として DLメチオニン $\left(10^{-3} \mathrm{~mol} \cdot \mathrm{dm}^{-3}, 5 \mathrm{~cm}^{3}\right)$ を用いて共存物質の影響を 検討した。

表 2 に示すよらに，無機塩類については 1000 倍モルまでの硝 酸カリウム, 硫酸ナトリウム, 塩化アンモニウム, 塩化マグネシ ウム, 塩化カルシウム, 塩化バリウム, 塩化マンガン, 硝酸スト ロンチウム, 硫酸亚鉛, 600 倍モルまでの硝酸アルミニウム, 400 倍モルまでの硝酸カドミウム, 200 倍モルまでの塩化鉄(III), 100 倍モルまでの硝酸ニッケル, 硝酸鉛, リン酸水素二ナトリウム 10 倍モルまでの塩化水銀 (II) 拈よび 0.2 倍モルまでの硫酸鉄( II )が 共存しても $3 \%$ 以内の相対誤差と $0.7 \%$ 以内の変動係数で定量が 可能であった。また，100倍モルまでのレーアルギニン，DLーアスパ

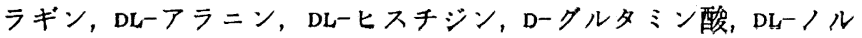

Table 2 Effect of concomitant compounds on the determination of DL-methionine

\begin{tabular}{|c|c|c|c|}
\hline Compound & $\begin{array}{c}\begin{array}{c}\text { Molar ratio } \\
\text { Compound }\end{array} \\
\text { DL-Methionine }\end{array}$ & $\begin{array}{l}\text { Relative } \\
\text { error } \\
\quad(\%)\end{array}$ & $\begin{array}{l}\text { Coefficient } \\
\text { of } \\
\text { variation } \\
(\%)\end{array}$ \\
\hline $\mathrm{KNO}_{3}$ & 1000 & -0.5 & 0.4 \\
\hline $\mathrm{Na}_{2} \mathrm{SO}_{4}$ & 1000 & +0.6 & 0.3 \\
\hline $\mathrm{NH}_{4} \mathrm{Cl}$ & 1000 & -0.2 & 0.4 \\
\hline $\mathrm{Na}_{2} \mathrm{HPO}_{4}$ & 100 & $-0.0_{4}$ & 0.2 \\
\hline $\mathrm{MgCl}_{2}$ & 1000 & +0.2 & 0.2 \\
\hline $\mathrm{CaCl}_{2}$ & 1000 & +0.2 & 0.4 \\
\hline $\mathrm{BaCl}_{2}$ & 1000 & +0.3 & 0.4 \\
\hline $\mathrm{MnCl}_{2}$ & 1000 & -0.3 & 0.2 \\
\hline $\mathrm{Sr}\left(\mathrm{NO}_{3}\right)_{2}$ & 1000 & -1.3 & 0.7 \\
\hline $\mathrm{ZnSO}_{4}$ & 1000 & +3.0 & 0.7 \\
\hline $\mathrm{Cd}\left(\mathrm{NO}_{3}\right)_{2}$ & 400 & -0.1 & 0.2 \\
\hline $\mathrm{Ni}\left(\mathrm{NO}_{3}\right)_{2}$ & 100 & -0.3 & 0.1 \\
\hline $\mathrm{Pb}\left(\mathrm{NO}_{3}\right)_{2}$ & 100 & -0.3 & 0.3 \\
\hline $\mathrm{HgCl}_{2}$ & 10 & +0.2 & 0.1 \\
\hline $\mathrm{FeSO}_{4}$ & 0.2 & +3.0 & 0.7 \\
\hline $\mathrm{FeCl}_{3}$ & 200 & +0.3 & 0.3 \\
\hline $\mathrm{Al}\left(\mathrm{NO}_{3}\right)_{3}$ & 600 & -0.4 & 0.3 \\
\hline L-Arginine & 100 & +0.1 & 0.2 \\
\hline DL-Asparagine & 100 & +0.2 & 0.4 \\
\hline DL-Alanine & 100 & $-0.0_{3}$ & 0.1 \\
\hline DL-Histidine & 100 & +0.4 & 0.4 \\
\hline D-Glutamic acid & 100 & -0.5 & 0.4 \\
\hline DL-Norleucine & 100 & -0.1 & 0.1 \\
\hline DL-Proline & 100 & $-0.0_{3}$ & 0.1 \\
\hline DL-Phenylalanine & 100 & +1.5 & 0.3 \\
\hline $\mathrm{DL}$-Serine & 100 & $-0.0_{3}$ & 0.3 \\
\hline DL-Threonine & 100 & +0.1 & 0.2 \\
\hline DL-Valine & 100 & -0.2 & 0.2 \\
\hline L-Cystine & 0.02 & +4.4 & 0.4 \\
\hline L-Cysteine & 0.02 & +2.8 & 0.3 \\
\hline DL-Tryprophan & 0.02 & +2.0 & 0.3 \\
\hline $\mathrm{L}-$ Tyrosine & 0.02 & +1.3 & 0.5 \\
\hline Vitamin $\mathrm{B}_{6}$ & 60 & -0.1 & 0.1 \\
\hline Mannitol & 100 & -0.1 & 0.1 \\
\hline Lactose & 100 & -0.2 & 0.4 \\
\hline Sorbitol & 100 & +0.2 & 0.2 \\
\hline
\end{tabular}

Sample : $10^{-3} \mathrm{~mol} \cdot \mathrm{dm}^{-3}$ DL-methionine $5 \mathrm{~cm}^{3}$, Titrant : $5 \times 10^{-3} \mathrm{~mol} \cdot \mathrm{dm}^{-3} \mathrm{KIO}_{3}$.

a) Ayerage of $3 \sim 4$ titrations. 
Table 3 Determination of DL-methionine and DL-methionine sulfoxide

\begin{tabular}{|c|c|c|c|c|c|c|}
\hline & \multicolumn{2}{|c|}{$\begin{array}{l}\text { Concentration } \\
\left(\mathrm{mol} \cdot \mathrm{dm}^{-3}\right)\end{array}$} & \multicolumn{2}{|c|}{$\begin{array}{l}\text { Analytical value } \\
(\mathrm{mg})\end{array}$} & \multirow{2}{*}{$\begin{array}{c}\text { Relative } \\
\text { error } \\
(\%)\end{array}$} & \multirow{2}{*}{$\begin{array}{l}\text { Coefficient } \\
\text { of } \\
\text { variation } \\
(\%)\end{array}$} \\
\hline & Sample $e^{b)}$ & $\mathrm{KIO}_{3}$ & Taken & Found $^{(a)}$ & & \\
\hline \multirow{8}{*}{ DL-Methionine } & $4 \times 10^{-3}$ & $10^{-1}$ & 29. 46 & 29.42 & -0.1 & 0.0 \\
\hline & $2 \times 10^{-3}$ & $10^{-1}$ & 14.73 & 14.70 & -0.2 & 0.1 \\
\hline & $8 \times 10^{-4}$ & $10^{-2}$ & 5. 756 & 5.756 & -0.2 & 0.2 \\
\hline & $4 \times 10^{-4}$ & $10^{-2}$ & 2. 889 & 2.889 & +0.2 & 0.1 \\
\hline & $2 \times 10^{-4}$ & $10^{-2}$ & 1. 442 & 1. 446 & +0.3 & 0.2 \\
\hline & $8 \times 10^{-5}$ & $10^{-8}$ & 0.5892 & 0.5951 & +1.0 & 0.1 \\
\hline & $4 \times 10^{-5}$ & $10^{-8}$ & 0.2946 & 0.3029 & +2.8 & 0.1 \\
\hline & $2 \times 10^{-5}$ & $10^{-3}$ & 0.1473 & 0.1543 & +4.8 & 0.4 \\
\hline \multirow{5}{*}{$\begin{array}{l}\text { DL-Methionine } \\
\text { sulfoxide }\end{array}$} & $8 \times 10^{-4}$ & $10^{-2}$ & 6. 472 & 6. 479 & +0.1 & 0.1 \\
\hline & $4 \times 10^{-4}$ & $10^{-2}$ & 3. 236 & 3.236 & \pm 0.0 & 0.1 \\
\hline & $2 \times 10^{-4}$ & $10^{-2}$ & 1. 618 & 1. 618 & \pm 0.0 & 0.2 \\
\hline & $8 \times 10^{-5}$ & $10^{-3}$ & 0.6472 & 0.6580 & +1.7 & 0.1 \\
\hline & $4 \times 10^{-5}$ & $10^{-8}$ & 0. 3236 & 0.3366 & +4.0 & 0.2 \\
\hline
\end{tabular}

a) Average of four titrations.

b) Sample solution : $50 \mathrm{~cm}^{8}$.

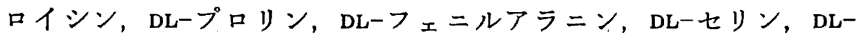
トレオニン, DL-バリン, マソニトール, ラクトース, ソルビトー ル, 60 倍モルまでのビタミン $\mathrm{B}_{6}$ が共存しても DL-メチオニンを $1.5 \%$ 以内の相対誤差と $0.4 \%$ 以内の変動係数で定量でさること がわかった。L-シスチン，L-システイン，DLートリプトファンおよ び L-チロシンは本実験条件下でョウ素酸イオンと反応 ${ }^{12115) 16)} す$ るため滴定に影響するものと考えられる。

\section{7 定量限界の精度}

本法による定量可能な濃度範囲と正確度および精度について検 討した。

表 3 に示すよらに, DL-メチオニンの場合には $2 \times 10^{-5} \sim 4 \times$ $10^{-3} \mathrm{~mol} \cdot \mathrm{dm}^{-3}$ の濃度範囲で $5 \%$ 以内の相対誤差と $0.4 \%$ 以内 の変動係数で定量可能であり, $2 \times 10^{-4} \sim 4 \times 10^{-3} \mathrm{~mol} \cdot \mathrm{dm}^{-3}$ の濃 度の場合には相対誤差, 変動係数ともに $0.3 \%$ 以内でもっとも精 度のよい分析值を与えた。また DL-メチオニンスルホキシドの場 合には, $4 \times 10^{-5} \sim 8 \times 10^{-4} \mathrm{~mol} \cdot \mathrm{dm}^{-3}$ の濃度籁囲で $4 \%$ 以内の相 対誤差と $0.2 \%$ 以内の変動係数で定量でき， (2〜8) $\times 10^{-4} \mathrm{~mol}$. $\mathrm{dm}^{-3}$ の濃度において $0.2 \%$ 以内の相対䛊差と変動係数でもっと も精度よく定量できることが明らかになった。

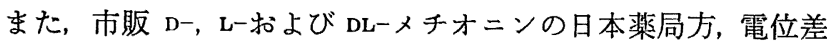
滴定法および本法による分析結果と $95 \%$ 信頼限界を表 4 に示し た。この分析結果を用いて本法と他の 2 方法について一般的な分 散（ $F$ 検定）㧊よび平均值の差（ $t$-検定）を検定したところ，各 メチオニンの分析值には分散および平均值の差に有意差は認めら れなかった。

15）池田早苗，佐竹 弘， 日本分析化学会第 33 年会講演要旨 集, p. 871(1984).

16）池田早苗，佐竹 弘，高島 章，日本化学会中国四国・九 州合同大会講演予稿集, p. 178(1982).
Table 4 Comparison of the results obtained by various methods

\begin{tabular}{|c|c|c|c|}
\hline \multirow{2}{*}{ Sample } & \multicolumn{3}{|c|}{ Purity $(\%)^{a)}$} \\
\hline & $\begin{array}{l}\text { Present } \\
\text { method }\end{array}$ & J. P. method & $\begin{array}{l}\text { Potentio- } \\
\text { metry }\end{array}$ \\
\hline DL-Methionine & $\begin{array}{l}99.78 \pm 0.19 \\
99.40 \pm 0.17\end{array}$ & $\begin{array}{l}99.56 \pm 0.26 \\
99.46 \pm 0.37\end{array}$ & $\begin{array}{l}99.69 \pm 0.18 \\
99.51 \pm 0.19\end{array}$ \\
\hline L-Methionine & $\begin{array}{l}99.53 \pm 0.20 \\
99.38 \pm 0.21\end{array}$ & $\begin{array}{l}99.21 \pm 0.28 \\
99.19 \pm 0.07\end{array}$ & $\begin{array}{l}99.32 \pm 0.13 \\
99.67 \pm 0.50\end{array}$ \\
\hline D-Methionine & $99.38 \pm 0.08$ & $99.30 \pm 0.14$ & $99.50 \pm 0.14$ \\
\hline
\end{tabular}

a) Average of five titrations.

b) Chloramine $\mathrm{T}$ method ${ }^{101}$.

\section{4 結 言}

回転白金電極を指示電極, SCE を対極とする電流滴定法によ り，〈チオニンとメチオニンスルホキシドをヨウ素酸カリウム標 準液で滴定する方法を確立した。

推鹰する方法はつぎのようになる。滴定セルに $10 \mathrm{~mol} \cdot \mathrm{dm}^{-3}$ 塩酸 $15 \mathrm{~cm}^{3}$, 結晶塩化ナトリウム $12 \mathrm{~g}$ と水 $25 \mathrm{~cm}^{3}$ を添加して 約 $45^{\circ} \mathrm{C}$ とする。これに $2 \sim 3 \mathrm{mg}$ のメチオニンまたはメチオニン スルホキシドを含む試料溶液 $10 \mathrm{~cm}^{3}$ をはかりとる。回転白金電 極 (+0.6 V vs. SCE) と SCE を浸し, 約 $45^{\circ} \mathrm{C}$ で $10^{-2} \mathrm{~mol}$. $\mathrm{dm}^{-3}$ ヨウ素酸カリウム標準液を 5 秒ごとに $0.05 \mathrm{~cm}^{3}$ ずつ滴下 して電流滴定する。

本法は JIS 標準試薬のヨウ素酸カリウムを滴定凧に用いるた めに，標準液の調製が容易で，標定操作の必要がなく，簡単迅速 にメチオニンおよびメチオニンスルホキシドを直接定量できると いう特徵がある。

(1983 年 4 月, 日本化学会第 47 春季年会(一部)発表) 


\section{Amperometric Titration of Methionine and "Methionine Sulfoxide" with Potassium lodate ${ }^{\dagger}$ \\ Sanae IKEDA* and Hiromu SATAKE \\ Technical College, The University of Tokushima; Minamijosanjima-cho, Tokushima-shi 770 Japan}

An amperometric titrimetry for the determination of methionine and methionine sulfoxide was developed. Detecting the end point by the reduction current of iodate(titrant) at a rotating platinum electrode $(2000 \mathrm{rpm})$ applying $+0.6 \mathrm{~V}$ vs. SCE, methionine and methionine sulfoxide could be titrated at about $45^{\circ} \mathrm{C}$ with $0.05 \mathrm{~cm}^{3}$ portions of a standard potassium iodate solution at intervals of $5 \sim 40 \mathrm{~s}$ by using a base solution of $3 \mathrm{~mol} \cdot \mathrm{dm}^{-3}$ hydrochloric acid saturated with sodium chloride. Methionine $(0.15 \sim 29 \mathrm{mg})$ and methionine sulfoxide $(0.34 \sim 6.5 \mathrm{mg}$ ) were determined with relative errors of less than $5 \%$. The best results were obtained in the sampling range of $1.5 \sim 29 \mathrm{mg}$ for methionine and $1.6 \sim 6.5 \mathrm{mg}$ for methionine sulfoxide with relative errors and coefficients of variation of less than $0.3 \%$. The recommended procedure is as follows. Measure $15 \mathrm{~cm}^{3}$ of $10 \mathrm{~mol} \cdot \mathrm{dm}^{-3}$ hydrochloric acid, $12 \mathrm{~g}$ of sodium chloride and $25 \mathrm{~cm}^{3}$ of water into a $100 \mathrm{~cm}^{3}$ titration cell. Heat it to about $45^{\circ} \mathrm{C}$ and add exacetly $10 \mathrm{~cm}^{3}$ of an aqueous solution containing $2 \sim 3 \mathrm{mg}$ of methionine or methionine sulfoxide. Titrate immediately the resultant solution at about $45^{\circ} \mathrm{C}$ with $0.05 \mathrm{~cm}^{3}$ portions of $10^{-2} \mathrm{~mol} \cdot \mathrm{dm}^{-3}$ standard potassium iodate solution at intervals of $5 \mathrm{~s}$ amperometrically. Effect of concomitant compounds were also investigated.

† Studies on Analytical Methods by Amperometric Titration Using a Rotating Platinum Electrode. LI. 